\title{
Column 6 \\ Stakeholder Perception and Empirical Evidence: Oil Palm Biomass Utilization as Climate-Smart Smallholder Practice
}

\author{
Sachnaz Desta Oktarina, Ratnawati Nurkhoiry, Rizki Amalia, \\ and Zulfi Prima Sani Nasution
}

Little is known about smallholder perception and adaptation of climate-smart practices. More precisely, smallholder's oil palm plots were frequently accused of being the driving force of ecosystem service depletion. This was arguably due to the vicious cycle facing the smallholder as the push factor. At first, smallholders did not plant legitim seeds and were not equipped with good agricultural practices (GAP), which decreased productivity. Since their earnings are low, they are motivated to expand the farm through deforestation (Bennett et al. 2018). This low-income situation is mainly due the absence of other income-generating activities to support their livelihoods. In the long run, this kind of practice has caused climate change. Scientists have suggested that climate-smart agricultural (CSA) practices are applied by smallholders in order to overcome this problem. Fortunately, palm oil plantation has offered a pull factor to answer this challenge. Palm oil biomass utilization might act as a pull factor that can be performed to the smallholder context. Specifically, palm oil products are cheap and eco-friendly because they have ubiquitous and versatile functions, ranging from food to fuel. In addition, little is known that we still can make the most of its left-over as well. Indonesian oil palm smallholders might apply oil palm biomass to grow food; make crafts; or use as wood, fiber, and energy. Thus, the versatility of palm oil definitely mitigates depletion of the environment and its use can be expanded to other smallholders nationwide. The act of using biomass is also considered to be a CSA practice that is specific to oil palm plantations. While most studies have examined CSA in terms of mechanistic or biophysical aspects, relatively little research has examined the interest, perception, or acceptance of CSA in oil palm cultivation, particularly among smallholders.

This research was supported by INSINAS Research Grant No: 18/INS-1/PPK/E4/2019.

S. D. Oktarina $(\bowtie) \cdot R$. Nurkhoiry $\cdot$ R. Amalia $\cdot$ Z. P. S. Nasution Indonesian Oil Palm Research Institute, Kota Medan, North Sumatera, Indonesia e-mail: sachnazdo@iopri.org 
A study to assess stakeholder perception and the implementation of biomass utilization as a CSA by smallholders was performed in case studies in Indonesia. The Labuhan Batu $(n=24)$, Batu Bara $(n=29)$, Langkat $(n=14)$, and Serdang Bedagai ( $n=32$ smallholders) districts were selected as sample cases in North Sumatra Province where numerous oil palm concessions are located (Ministry of Agriculture Decree no. 833/KPTS/SR.020/M/12/2019). The first phase of the study was conducted by quasi-qualitative text mining and sentiment analysis (Pang and Lee 2008) to decode smallholder, practitioner, and expert's perceptions and sentiments regarding oil palm biomass products in small-medium enterprise (SME) schemes. The next phase of implementation was undertaken by introducing farmers to oil palm biomass-derived products, such as empty fruit bunch briquettes, oil palm frond pellets, midrib handicraft, oil palm based-livestock feed, empty fruit bunch oyster mushrooms, oil palm juice brown sugar, oil palm-laminated wood, and empty fruit bunch-compost. The feasibility and preferences among these alternatives were then assessed by multi-criteria decision-making tools in what is referred to as an Analytical Hierarchy Process (AHP) based on the benefit (B), opportunity (O), cost (C), and risk (R) features, as illustrated in Table C6.1. The text mining analysis revealed that, initially, the smallholders were perceived to have a lower interest in making use of oil palm biomass. It was suggested that they expected a higher incentive to adopt it in smallholder groups (Kehinde et al. 2019). It was also still unclear whether they realize and understand the potential of biomass utilization to save the environment and restore ecological services. The word cloud shown in Fig. C6.1 showed that none of the smallholders considered either sustainability or environmental services. They also had little enthusiasm towards the project since they depend on the mini palm oil mill more than the biomass utilization itself. They were reluctant to employ only biomass utilization as it perpetuates smallholder marginalization. Moreover, aside from their concerns related to accessing feedstock and raw materials, they also anticipated obtaining income immediately after the biomass utilization practices were conducted. However, the other two stakeholders revealed

Table C6.1 Biomass utilization alternatives in view of its benefit, opportunity, cost, and risk

\begin{tabular}{|c|c|c|c|c|c|c|}
\hline Criteria & Sub-criteria & Briquette & Handicraft & Mushroom & $\begin{array}{l}\text { Oil Palm } \\
\text { Sugars }\end{array}$ & Compost \\
\hline \multirow[t]{2}{*}{ B } & Income & $\begin{array}{l}\text { Rp } 18 \mathrm{M} / \\
\text { month }\end{array}$ & $\begin{array}{l}\text { Rp } 5 \mathrm{M} / \\
\text { month; }\end{array}$ & $\begin{array}{l}\text { Rp } 9 \text { M/ } \\
\text { month; }\end{array}$ & $\begin{array}{l}\text { Rp } 23.5 \mathrm{M} / \\
\text { month; }\end{array}$ & $\begin{array}{l}\text { Rp } 20 \text { M/ } \\
\text { month; }\end{array}$ \\
\hline & Labour & 3 people & 5 people & 2 people & 4 people & $>10$ people \\
\hline \multirow[t]{2}{*}{$\mathbf{O}$} & $\begin{array}{l}\text { Raw } \\
\text { material }\end{array}$ & $\begin{array}{l}5 \mathrm{MT} / \mathrm{ha} / \\
\text { year }\end{array}$ & $\begin{array}{l}350 \mathrm{~kg} / \mathrm{ha} / \\
\text { year }\end{array}$ & $\begin{array}{l}5 \mathrm{MT} / \mathrm{ha} / \\
\text { year }\end{array}$ & 7-9 L/tree & $\begin{array}{l}5 \mathrm{MT} / \mathrm{ha} / \\
\text { year }\end{array}$ \\
\hline & Market & $\begin{array}{l}\text { Domestic } \\
\text { use fuel }\end{array}$ & $\begin{array}{l}\text { Creative } \\
\text { industry }\end{array}$ & Healthy food & $\begin{array}{l}\text { Oil palm } \\
\text { sugars }\end{array}$ & $\begin{array}{l}\text { Organic } \\
\text { fertilizer }\end{array}$ \\
\hline \multirow[t]{2}{*}{$\mathbf{C}$} & Investment & $\mathrm{Rp} 70 \mathrm{M}$ & Rp $5 \mathrm{M}$ & Rp $30 \mathrm{M}$ & $\mathrm{Rp} 35 \mathrm{M}$ & Rp $600 \mathrm{M}$ \\
\hline & Operational & $\begin{array}{l}\text { Rp } 18 \mathrm{M} / \\
\text { month }\end{array}$ & $\begin{array}{l}\text { Rp } 7.4 \mathrm{M} / \\
\text { month }\end{array}$ & $\begin{array}{l}\text { Rp } 4.5 \mathrm{M} / \\
\text { month }\end{array}$ & $\begin{array}{l}\text { Rp } 25 \mathrm{M} / \\
\text { month }\end{array}$ & $\begin{array}{l}\text { Rp } 40 \mathrm{M} / \\
\text { month }\end{array}$ \\
\hline \multirow[t]{2}{*}{$\mathbf{R}$} & Market & High & High & Low & Low & Low \\
\hline & Environment & Low & Low & Low & Low & Low \\
\hline
\end{tabular}



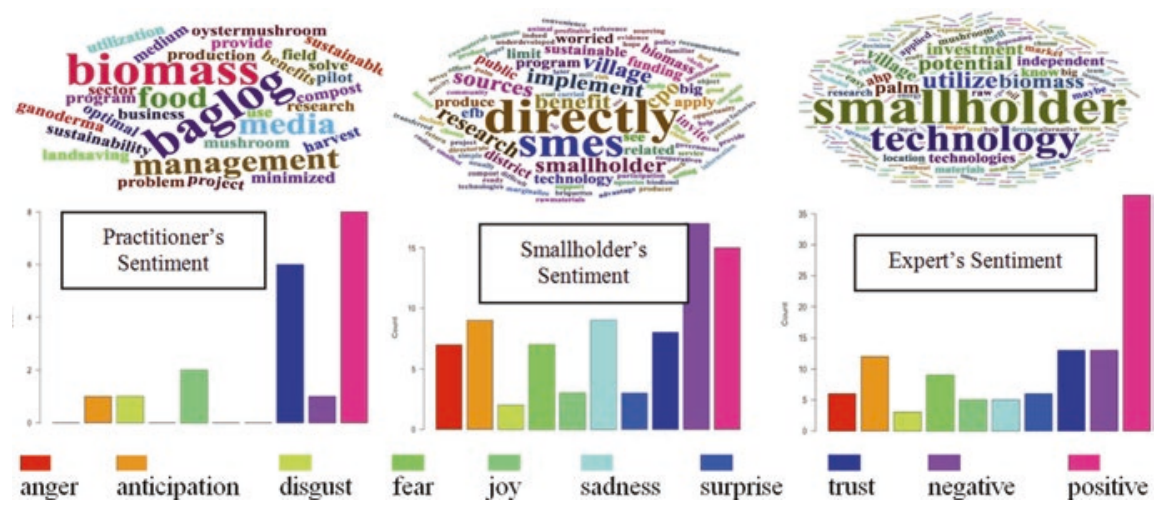

Fig. C6.1 Word cloud and sentiment analysis results of stakeholder perception towards biomass utilization

that they had generally positive sentiments towards the CSA of biomass utilization. The findings showed that the two groups were enthusiastic and showed considerable awareness towards the projects. The practitioners shared their experiences in how it could be successfully executed while maintaining nature's carrying capacity. The experts were convinced of the benefits and feasibility of the program to be applied to SME that is suitable with smallholder's institutional arrangement. They also highlighted the importance of low investment cost, the site-specific potential, and the need for alternative income-generating activities as these related to biomass utilization. Overall, both practitioners and experts agreed to provide assistance to smallholders and facilitate access to raw materials and a capacity building program for them. Eventually, immediately after implementation, the smallholders were enlightened and selected biomass utilization technology as a pluri-activity. The AHP results (ordinal ranking) suggested that midrib handicrafts were dominant, followed by the oyster mushroom, empty fruit bunch compost, briquettes, and oil palm sugars were most feasible products according to the smallholder's point of view (AHP scores: $0.228,0.139,0.128,0.122$, and 0.117 respectively). It showed the midrib handicraft was mostly selected due to its lower investment costs, despite returning the lowest disposable incomes (5 million IDR per month) compared to other biomass products. Since these shareholders do not generate enough money to invest, they tend to be risk-averse in their selection. However, it is necessary to provide an incentive scheme that might encourage smallholders to adapt. In doing so, the climate-smart adaptation practices are considered feasible and expandable and can be applied nationwide for the sustainability of the people, the profit, and the planet. 


\section{References}

Bennett A, Ravikumar A, Paltán H (2018) The political ecology of oil palm company-community partnerships in the Peruvian Amazon: deforestation consequences of the privatization of rural development. World Dev 109:29-41

Kehinde MO, Shittu AM, Osunsina IOO (2019) Willingness to accept incentives for a shift to climate-smart agriculture among lowland Rice farmers in Nigeria. Nigerian J Agric Econ 9(2066-2020-1439):29-44

Pang B, Lee L (2008) Opinion mining and sentiment analysis. Found Trends Inf Retr 2(1-2):1-135

Open Access This chapter is licensed under the terms of the Creative Commons Attribution 4.0 International License (http://creativecommons.org/licenses/by/4.0/), which permits use, sharing, adaptation, distribution and reproduction in any medium or format, as long as you give appropriate credit to the original author(s) and the source, provide a link to the Creative Commons license and indicate if changes were made.

The images or other third party material in this chapter are included in the chapter's Creative Commons license, unless indicated otherwise in a credit line to the material. If material is not included in the chapter's Creative Commons license and your intended use is not permitted by statutory regulation or exceeds the permitted use, you will need to obtain permission directly from the copyright holder.

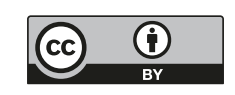

